\title{
PENGEMBANGAN DAN PELATIHAN PENGGUNAAN E-LEARNING PADA SMPN 7 BANJARMASIN
}

\author{
Joni Riadi ${ }^{1}$, Wanvy Arifha Saputra ${ }^{2}$, Saberan ${ }^{3}$, Yoenie Indrasary ${ }^{4}$ \\ Politeknik Negeri Banjarmasin 1,2,3,4 \\ joni.riadi@poliban.ac.id ${ }^{1}$,wanvysaputra@poliban.ac.id ${ }^{2}$, saberan@poliban.ac.id ${ }^{3}$, \\ yoenie.indrasary@poliban.ac.id ${ }^{4}$
}

\begin{abstract}
The Community Service Activities program were carried out at SMPN 7 Banjarmasin. It Based on field surveys, for teaching and learning activities using manual methods and do not yet have e-learning system. Utilization of manual methods supported by e-learning as a means of effective teaching and learning activities. E-learning is built to accommodate teachers in providing learning needs for students. Learning needs such as learning materials that can be accessed anytime and anywhere, efficient in storing teaching materials and assignments, and practical in their use. The targets and targets obtained from community service activities are 3: Making a school website can accommodate school profiles online, making E-learning facilitates teaching and learning activities among teachers and students, and making the IMPACT service journal as a report on community service activities that can be accessed by the public. This community service activity was carried out on Saturday, September 7, 2019 inside the Computer Laboratory, attended by 4 lecturers, 3 students, and 27 participants. It is hoped that this activity will be beneficial for school residents in accessing teaching materials easily, efficiently, can be done whenever and wherever they are without knowing the distance and time.
\end{abstract}

Keywords: e-learning, school, technology utilization

\begin{abstract}
ABSTRAK
Kegiatan Pengabdian Kepada Masyarakat ini dilaksanakan di SMPN 7 Banjarmasin. Berdasarkan survey lapangan, di SMPN 7 Banjarmasin untuk proses kegiatan belajar mengajar sepenuhnya menggunakan metode manual dan belum memiliki e-learning sekolah. Pemanfaatan metode manual sepenuhnya tersebut dapat ditingkatkan dengan penambahan e-learning sebagai sarana kegiatan belajar mengajar yang efektif. E-learning yang dibangun guna mengakomodasi guru dalam memberikan kebutuhan belajar pada siswa. Kebutuhan belajar tersebut seperti bahan belajar yang dapat diakses kapan saja dan dimana saja, efisien dalam penyimpanan bahan ajar dan tugas, dan praktis pada penggunaannya. Target dan luaran yang dicapai dari kegiatan pengabdian kepada masyarakat ini ada 3 yaitu Pembuatan website sekolah dapat mengakomodasi profil sekolah secara online, Pembuatan E-learning mempermudah kegiatan belajar mengajar antara guru dan siswa. Dan Pembuatan Jurnal pengabdian IMPACT sebagai laporan kegiatan pengabdian yang dapat diakses publik. Kegiatan pengabdian masyarakat ini dilakukan pada hari Sabtu tanggal 07 September 2019 di ruangan Laboratorium Komputer dengan dihadiri dosen sejumlah 4 orang, mahasiswa 3 orang, dan peserta 27 orang. Diharapkan kegiatan ini bermanfaat guna warga sekolah dalam mengakses bahan ajar dengan mudah, efisien serta dapat dilakukan kapanpun dan dimanapun mereka berada tanpa mengenal jarak dan waktu.
\end{abstract}

Kata Kunci: e-learning, sekolah, pemanfaatan teknologi 


\section{PENDAHULUAN}

Perkembangan teknologi informasi memainkan peranan yang sangat penting dalam berbagai bidang, seperti industri, perdagangan, kesehatan, pendidikan dan sebagainya. Internet merupakan jaringan komputer global di seluruh dunia dan dapat diakses dimana saja dan kapanpun sebagai media komunikasi yang dapat memberikan berbagai informasi kepada publik. Suatu lembaga pendidikan pemerintah atau swasta dapat memberikan informasi atau ilmu dengan melalui bahan ajar kepada warga sekolah. Akses Bahan ajar yang didukung dengan teknologi dan internet terdapat pada e-learning sekolah.

Dalam dunia pendidikan, salah satu dari kegiatan belajar mengajar ialah penyampaian informasi. Penyampaian informasi yang menarik dapat membuat siswa untuk memahami pembelajaran. Kegiatan belajar mengajar pada SMPN 7 Banjarmasin sepenuhnya menggunakan metode manual, seperti penulisan pada papan tulis, pendalaman materi lewat buku dan pengumpulan tugas berupa kertas atau makalah. Kegiatan tersebut memiliki dampak seperti membuat siswa kurang efektif menyerap informasi pelajaran, meja kerja guru yang dipernuhi tugas-tugas dari muridnya dan ketahanan terhadap kerusakan pada bahan ajar atau tugas yang bersifat fisik.

Berdasarkan masalah di atas, pengabdian akan dilakukan dengan membangun e-learning sekolah. Sehingga diharapkan dengan menggunakan e-learning yang berbasis web, warga sekolah dapat mengakses bahan ajar dengan mudah, efisien serta dapat dilakukan kapanpun dan dimanapun mereka berada tanpa mengenal jarak dan waktu.

\section{METODE KEGIATAN / SOLUSI / TEKNOLOGI /}

Metode pelaksanaan dalam kegiatan pengabdian kepada masyarakat ini berfokus pada sub bidang IPTEKS bagi masyarakat. Bidang ini menyajikan pendekatan dalam bentuk konsultasi, difusi IPTEK dan pelatihan. Konsultasi digunakan untuk kegiatan-kegiatan yang di dalamnya terdapat persoalan atau suati kebutuhan pada masyarakat yang dapat diselesaikan melalui sinergisme dengan perguruan tinggi, Difusi IPTEK digunakan untuk kegiatan yang menghasilkan produk bagi konsumen, dan pelatihan digunakan untuk kegiatan yang melibatkan penyuluhan tentang substansi kegiatan yang disertai dengan demonstrasi atau percontohan untuk realisasinya. Untuk pembagian secara rinci pada metode pelaksanaannya terdapat pada Gambar 1. 


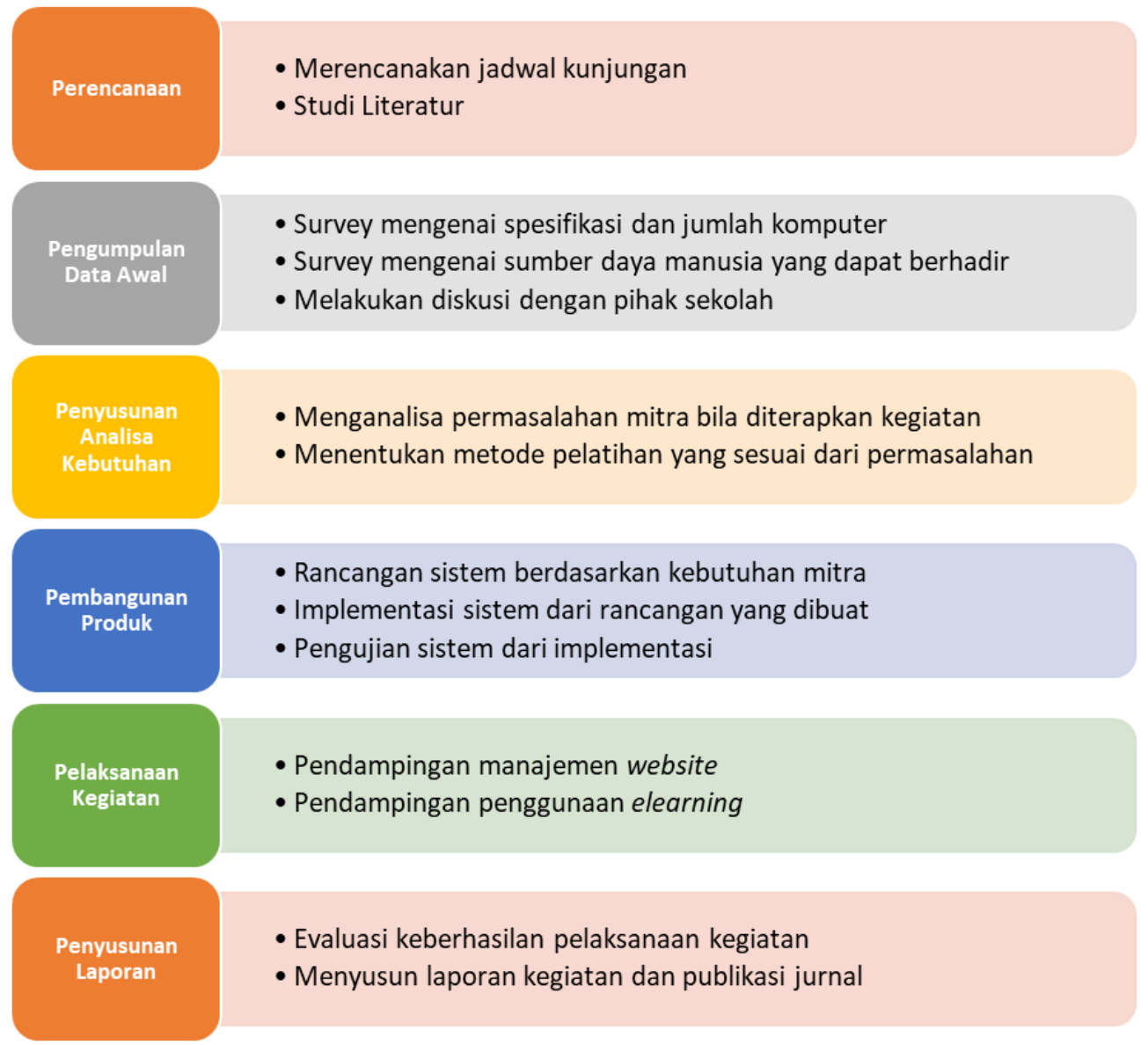

Gambar 1. Metode Pelaksanaan

Pada tahapan perencanaan, kegiatan pengabdian kepada masyarakat ini akan dilaksanakan pada jam kerja di SMPN 7 Banjarmasin dengan mendapatkan ijin dari kepala sekolahnya terlebih dahulu. Kemudian dilanjutkan dengan studi literatur terhadap kegiatan pengabdian masyarakat dengan memiliki topik yang mirip yaitu e-learning.

Pada tahapan pengumpulan data awal, melakukan diskusi dengan pihak sekolah terkait spesifikasi dan jumlah komputer yang dapat digunakan pada laboratorium komputer sekolah. Diskusi juga membahas tentang sumber daya manusia yang dapat berhadir saat pelaksanaan nantinya. Pada tahapan penyusunan analisa kebutuhan, melakukan analisa terkait permasalahan yang dihadapi pihak sekolah dan menentukan pelatihan yang diperlukan agar materi terserap efektif.

Pada tahapan pembangunan e-learning melakukan perancangan sistem berdasarkan kebutuhan, implementasi perancangan, dan pengujian dari hasil implementasi. Pada tahapan pelaksanaan kegiatan dengan melakukan pendampingan manajemen website dan pendampingan penggunaan e-learning. Dan terakhir adalah penyusunan laporan kegiatan terkait evaluasi keberhasilan dan menyusun laporan pelaksanaan. Setelah selesai kegiatan pengabdian kepada masyarakat ini, program masih berlanjut pada pemantauan penggunaan $e$ - 
learning. Apabila pihak sekolah menemukan masalah, para tim pelaksana kegiatan pengabdian kepada masyarakat siap untuk membantu selama dalam kurun waktu 1 tahun terhitung setelah pelatihan.

\section{HASIL DAN PEMBAHASAN}

Kegiatan pengabdian dilaksanakan pada hari sabtu, tanggal 07 September 2019, waktu 09.00 WITA di Laboratorium Komputer SMPN 7 Banjarmasin. Kegiatan ini dihadiri dosen sejumlah 4 orang, mahasiswa 3 orang, dan peserta 27 orang Untuk pengaturan tempat terdapat pada Gambar 2.

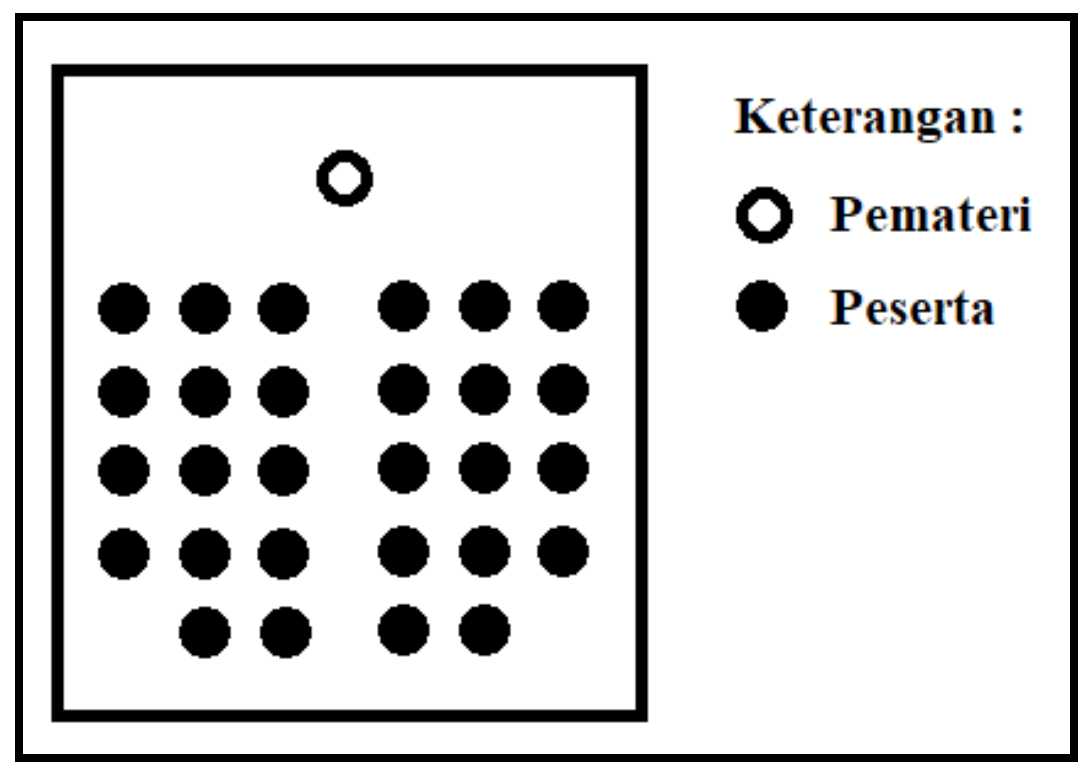

Gambar 2. Pengaturan Tempat

Luaran yang dicapai pada kegiatan ini adalah publikasi jurnal pengabdian, website sekolah, dan e-learning sekolah. Alamat website yang disepakati dengan pihak manajemen sekolah (Lampiran 02 - Surat kuasa dan Lampiran 03 - Surat permohonan domain) adalah www.smpn7-bjm.sch.id. Website sekolah mendukung fitur Sistem login, Manajemen Post, Manajemen Pages, Manajemen Menu, dan Manajemen User.

Situs e-learning dapat diakses dengan menggunakan aplikasi browser seperti google chrome, mozilla firefox, atau opera. E-learning pada kegiatan ini dipublikasi secara online melalui alamat www.elearning.smpn7-bjm.sch.id, sehingga dapat diakses kapanpun dan dimanapun. Untuk menu utama yang disediakan adalah sistem login, manajemen user, manajemen kategori, manajemen mata pelajaran, dan manajemen nilai siswa. Pada Gambar 3 merupakan capaian peserta tentang pemahaman penggunaan e-learning. Pada gambar tersebut, peserta tidak memahami proses manajemen matapelajaran dan manajemen nilai. Hal tersebut dikarenakan peserta yang masih awam akan teknologi dan sulit memahami bisnis proses dari menu tersebut. 


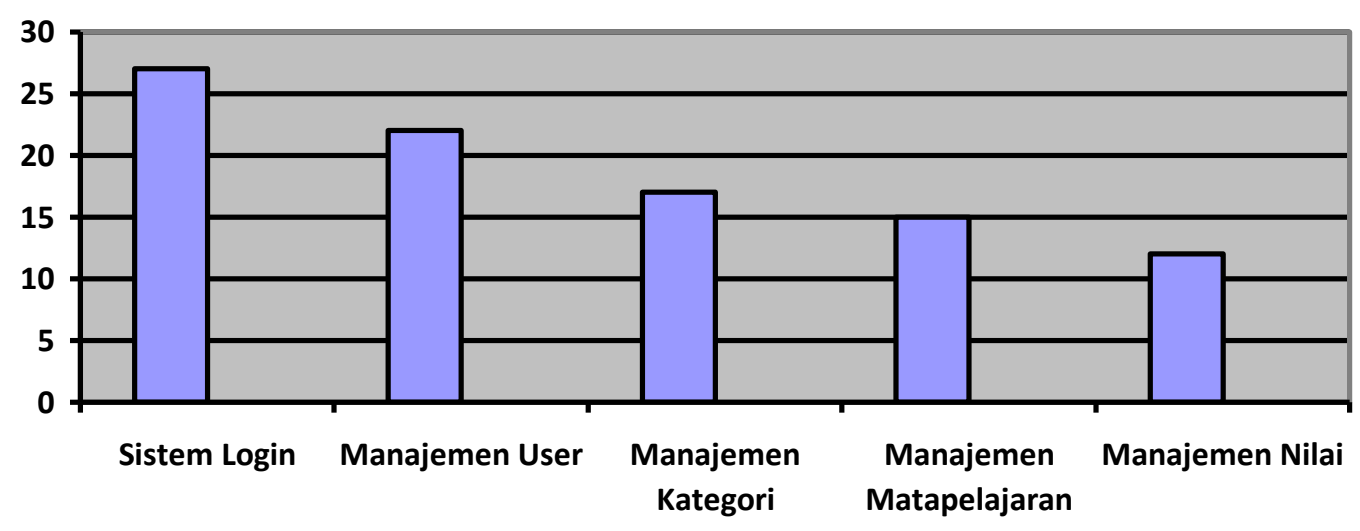

Gambar 3. Capaian Peserta tentang Pemahaman Penggunaan E-Learning

Dokumentasi kegiatan pengabdian meliputi pembukaan sebagaimana pada Gambar 4, pelaksanaan bimbingan / pelatihan pada Gambar 5, dan foto bersama pada Gambar 6. Keunggulan luaran pada kegiatan pengabdian ini adalah sistem informasi yang bersifat online, sehingga untuk pengaksesan dapat dilakukan dimanapun dan kapanpun. Kekurangan dari luaran ini adalah berbasis teknologi melalui komputer, sehingga peserta yang awam pada teknologi memiliki kesulitan dalam mengikuti pelatihannya sebagaimana pada Gambar 3. Tingkat kesulitan dalam kegiatan pengabdian ini adalah pemahaman peserta akan e-learning yang dibangun, dikarenakan e-learning merupakan sistem yang kompleks maka peserta harus mengenal dengan baik akan teknologi sebelumnya, untuk menutupi kelemahan tersebut, tim pengembang membuatkan modul e-learning sebagai pembelajaran dan konsultasi secara gratis via telepon.

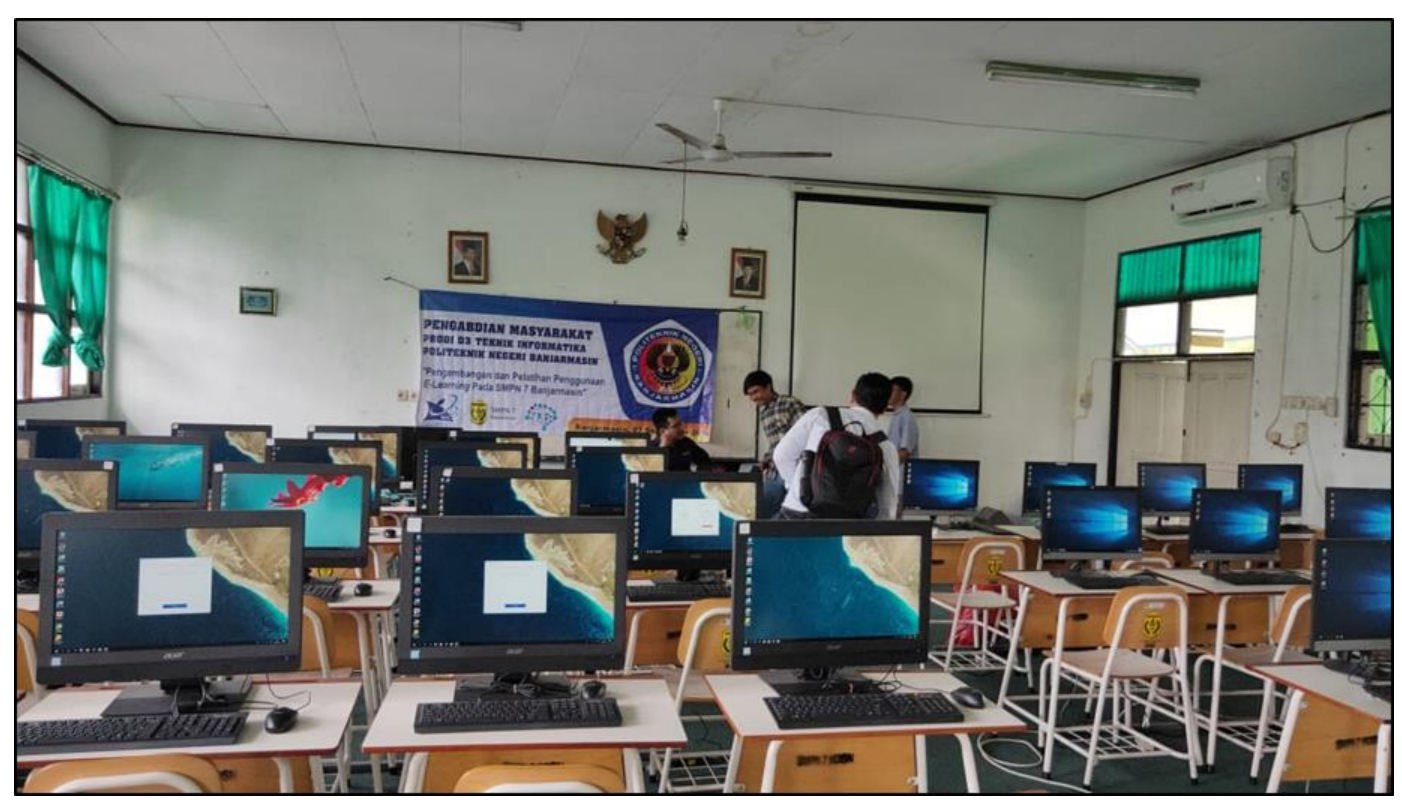

Gambar 4. Pembukaan 


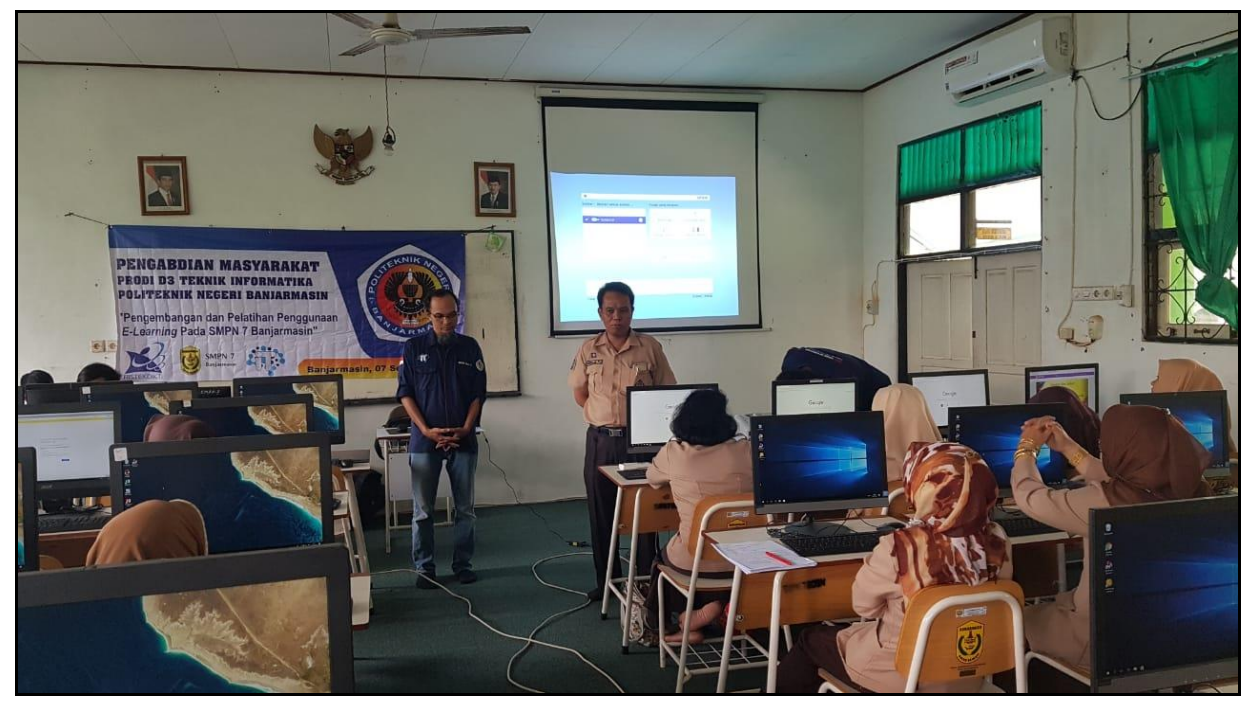

Gambar 5. Pelaksanaan Bimbingan / Pelatihan

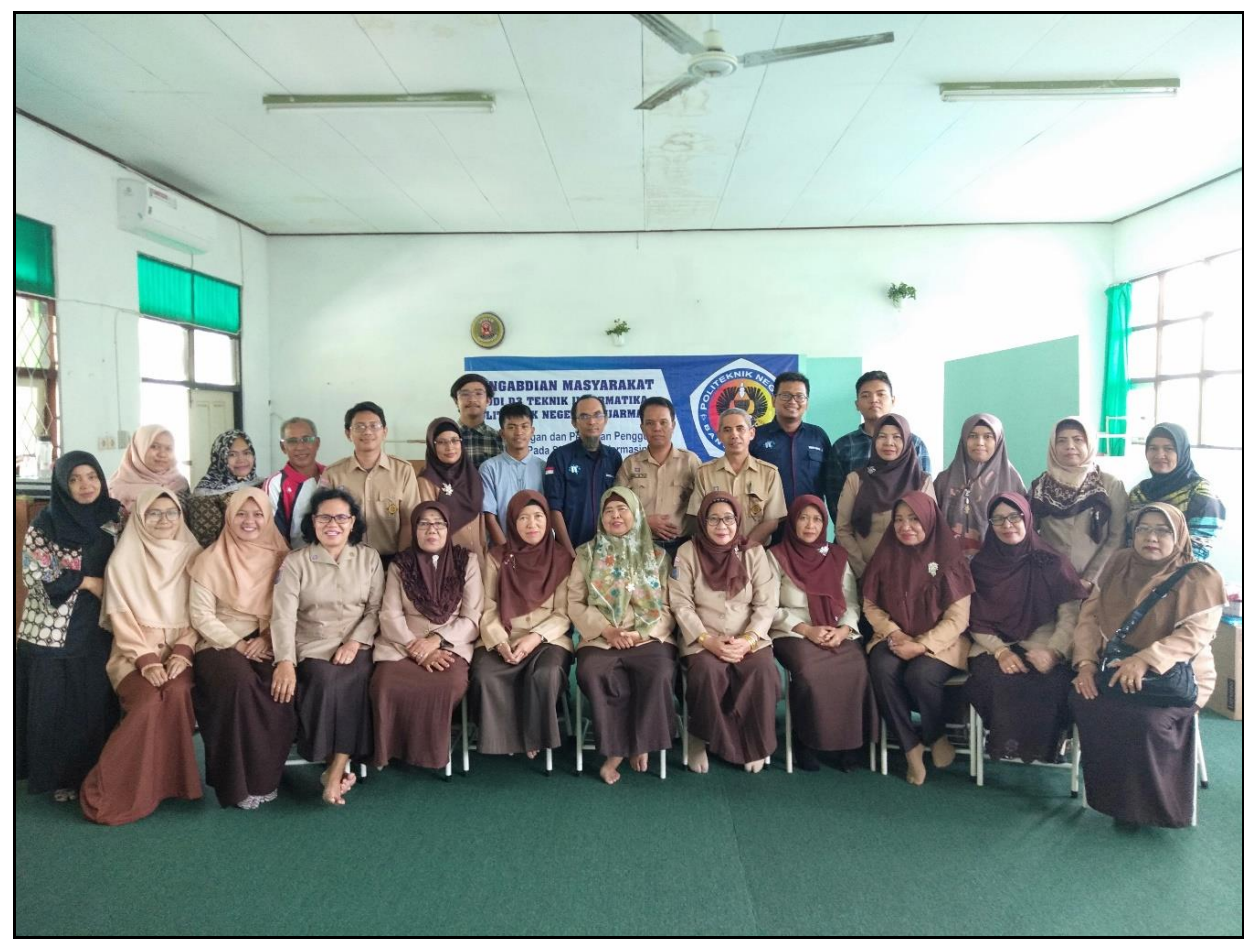

Gambar 6. Foto Bersama

\section{KESIMPULAN}

Melalui pembangunan dan pelatihan e-learning ini, maka akan sangat membantu sekali dalam penyampaian informasi proses belajar mengajar. Baik itu informasi teori dan ujian semester. Kegiatan pengabdian kepada masyarakat juga dapat berjalan dengan baik dengan mengikutsertakan peran mahasiswa sebagai pendamping peserta ketika proses pelatihan peserta. 


\section{UCAPAN TERIMA KASIH}

Kami ucapkan terimakasih banyak kepada Poliban melalui unit P3M yang telah membantu dalam pemberian dana hibah kegiatan pengabdian masyarakat.

\section{DAFTAR PUSTAKA}

Abdul Kadir, Pengenalan Sistem Informasi, Penerbit Andi Yogyakarta, Yogyakarta: 2002

Chandrawati, Rahayu. S., 2010, Pemanfaatan E-Learning dalam Pembelajaran, No.2, Vol.8, Jurnal Universitas Pertahanan.

Fathansyah, 1999, Basis Data, Informatika Bandung, Bandung.

Kurniawan, Yahya, 2004, Aplikasi Web Database dengan PHP dan MySQL, PT Elex Media Komputindo, Jakarta.

Nursalam dan Ferry Efendi, 2008, Pendidikan dalam Keperawatan, Jakarta:Salemba Medika

Purba S. D., Sopyan A., Hartono., 2006, Aktivitas Belajar Dan Penguasaan Materi Siswa dengan Pembelajaran Berbasis Portofolio pada Mata Pelajaran Sains Fisika SMP, Jurnal Pend. Fisika Indonesia, Vol.4, No.2 